\title{
Identifying Unregulated Emissions from Conventional Diesel Self-Ignition and PPCI Marine Engines at Full Load Conditions
}

\author{
Xi Wang ${ }^{1, *}$, Minfei Wang ${ }^{2}$, Yue Han ${ }^{3}$ and Hanyu Chen ${ }^{2, *}$ \\ 1 School of Physical Education, Jianghan University, Wuhan 430056, China \\ 2 School of Energy and Power Engineering, Wuhan University of Technology, Wuhan 430063, China; \\ chry0717@163.com \\ 3 Dingcheng Machinery Manufacturing Co. Ltd., Sihong Economic and Technological Development Zone, \\ Sihong 223900, China; xiaoyu000929@163.com \\ * Correspondence: wangxi050611024@126.com (X.W.); chyu@whut.edu.cn (H.C.)
}

Received: 19 January 2020; Accepted: 5 February 2020; Published: 8 February 2020

\begin{abstract}
A study on unregulated emissions of a conventional diesel self-ignition and partial premixed compression ignition (PPCI) marine engine at full load condition was performed, respectively. In this work, PPCI was realized in a marine engine by blending $15 \%$ diesel with $85 \%$ light hydrocarbons (LHC). Gas chromatography-mass spectrometry (GC-MS) was used to detect and identify unregulated emissions, and the chemical formula and peak area of representative species were obtained. Furthermore, the unregulated emissions were classified and semi-quantitatively analyzed. The results show that the maximum in-cylinder pressure of PPCI is almost 11 bar lower than that of conventional diesel combustion, and the crank angle at that moment is also delayed by $2{ }^{\circ} \mathrm{CA}$. Compared to conventional diesel combustion, the maximum pressure rise rate of PPCI is reduced by $3.5 \%$, while the maximum heat release rate of PPCI increases by $23.5 \%$. Further, PPCI produces fewer species in unregulated emissions, and their chemical formula are less complex than that of conventional diesel combustion. Compared to conventional diesel combustion, the relative concentration of alkane and organic components in PPCI decreases significantly, while ketone and ester increase.
\end{abstract}

Keywords: internal combustion engines; partial premixed compression ignition; unregulated emissions; gas chromatography-mass spectrometry

\section{Introduction}

Internal combustion engines are widely used in agriculture, transportation, and industry because of their high efficiency, good economy, and high reliability. However, the emission of internal combustion engines seriously affects the living environment of people [1]. At present, emission regulations mainly restrict regulated emissions such as $\mathrm{NOx}, \mathrm{HC}, \mathrm{CO}$, and PM. Nevertheless, in recent years, more and more attention has been paid to the unregulated emissions of internal combustion engines, such as alcohols, aldehydes, aromatics, and sulfides. Some species of the unregulated emissions, even in small concentrations in the air, have chronic toxicity. Their presence around the population has a great threat to people's health $[2,3]$.

Under the pressures of energy, environment, and health, the development and application of new alternative fuels has become a hot issue in the research of internal combustion engines. Currently, the most studied alternative fuels are alcohols (mainly including methanol and ethanol), biodiesel, and dimethyl ether. They come from a wide range of sources and are effective as oxygenated fuels to reduce particulate emissions. Qian et al. [4] conducted the experiments on the combustion and 
regulated/unregulated emissions characteristics in a gasoline direct injection (GDI) engine fueled with $\mathrm{C}_{3}-\mathrm{C}_{5}$ alcohols (ethanol, n-propanol, n-butanol, and npentanol). Cheung et al. [5] and Man et al. [6] investigated the regulated and the unregulated emissions of biodiesel at different speed and load conditions, including the two carbonyl compounds (formaldehyde and acetaldehyde), three unsaturated hydrocarbons (1,3-butadiene, propene, and ethene), and three aromatics (benzene, toluene, and xylene). However, relevant studies have found that the use of alcohol and ether fuels intensifies the production of unregulated emissions [5,7]. Agarwal et al. [8] carried out the exhaustive experiments on the effects of burning methanol- and ethanol-gasoline blends on the unregulated emissions. The results revealed that the concentrations of formic acid, iso-butane, and iso-pentane in gasohol blends are lower than that in baseline gasoline. Zhang et al. [9] applied diesel/fumigation methanol compound combustion scheme on a four-cylinder diesel engine and found the reduction of ethyne, ethylene, and 1,3-butadiene emissions. Nevertheless, the increase of methanol concentration in the test fuel was detrimental to higher emissions of benzene, toluene, xylene, unburned methanol, and formaldehyde.

In addition, some studies on the emissions of diesel blended with several hydrocarbon fuel surrogate components have been carried out. Tsunemoto et al. [10] studied the exhaust emission of the paraffinic hydrocarbons $\left(\mathrm{C}_{7}-\mathrm{C}_{12}\right)$ with different boiling points and aromatic hydrocarbons blended with paraffinic and olefinic hydrocarbons. Li et al. [11] studied n-dodecane, iso-dodecane, tetralin, and decalin, and analyzed in detail the differences of unregulated emissions of aldehyde, olefins, and methane fueled with diesel blending with $10 \%$ and $20 \%$ fuel components. In order to meet the requirements of fuel economy, power performance, and emission characteristics, some new concept combustion, such as homogeneous charge compression ignition (HCCI), premixed charge compression ignition (PCCI), and partially premixed compression ignition (PPCI) have been proposed in the recent years to reduce the regulated and unregulated emissions without compromising on engine efficiency. HCCI engines are faced with such challenges as controlled auto ignition, high pressure rise rate, load extension, combustion phasing control, high emissions of $\mathrm{CO}$ and $\mathrm{HC}$, and homogeneous charge preparation $[12,13]$. In PCCI or PPCI derived from HCCI, the end point of fuel injection and the start point of combustion are separated for preferred control over the start of combustion and better fuel-air premixed state at the beginning of combustion [14]. References [15-18] conducted numerical simulation or experimental study on PPCI combustion.

Due to the diversity of alternative fuels and combustion modes, there are hundreds of unregulated emission species. Therefore, it is necessary to establish a systematic and efficient detection method for unregulated emissions. At present, the main analytical instruments are Fourier transform infrared (FTIR), high performance liquid chromatography (HPLC), and gas chromatography/mass spectrometry (GC-MS). Qu et al. [19] conducted the experiments on a four-cylinder direct-injection spark-ignition (DISI) methanol engine. The measurement methods in which combine with gas chromatography and liquid chromatography were used to separate and measure regulated and unregulated emissions. Wang et al. [20] studied the influence of ash on the emissions. The regulated gaseous emissions, and the unregulated emissions (mainly carbonyl compounds and volatile organic compounds) were measured by a gaseous analyzer, electrical low pressure impactor (ELPI), HPLC, and GC-MS, respectively. Agarwal et al. [8] carried out exhaustive experiments fueled gasohol for characterizing the emissions. The regulated emissions and the unregulated emissions are measured by a raw exhaust emission analyzer and a FTIR emission analyzer, respectively.

Previous studies have been focused on the emission characteristics and regulated pollutants. In recent years, unregulated emissions have received increasing attention, but are mainly concentrated in biodiesel or alcohol-diesel blends. Most of the contents are focused on specific components (formaldehyde, acetaldehyde, 1,3-butadiene, and benzene) or further on the effects of load, rotational speed, injection timing, and ignition on these components $[6,21,22]$. There is lack of information on the unregulated emissions of diesel-light hydrocarbon fuels as applied to a diesel engine and the measurements of species are not entirely complete. Hence the aim of this study is to identify 
the unregulated emissions of a marine diesel engine fueled with diesel and light hydrocarbon blends in PPCI at full load, to further compare the results with those obtained in conventional diesel self-ignition combustion.

\section{Experimental Setup and Method}

The experiments were carried out on the basis of a six-cylinder prototype marine diesel engine manufactured by a Chinese automaker with the purpose of power generation. The prototype engine was refitted to realize PPCI where large amounts of LHC was injected into intake manifold by adopting PFI injector and then premixed LHC-air mixture was ignited by a small quantity of diesel directly injected (DI) into cylinder, and the schematic layout of the experimental setup was presented in Figure 1. In this study, the engine speed and torque were controlled automatically by using an electrical dynamometer (AVL504/4.6 SL). A piezoelectric pressure sensor (Kistler 6052C) along with a combustion analyzer (Dewetron M0391E) was adopted to acquire in-cylinder combustion pressure and corresponding crank angle. A shunt pipe was installed on the exhaust gases pipe to collect the exhaust gas in PPCI and conventional diesel self-ignition combustion, respectively. Under the action of gas sampling pump, exhaust gas was cooled down in the shunt pipe first, and then flowed through the activated carbon. The exhaust particulate impurities and macromolecular substances were absorbed by activated carbon. Finally, the filtered exhaust entered a florence flask with absorption liquid. The absorbent liquid was n-hexane with purity up to $99.99 \%$, which could absorb unregulated gaseous emissions from the exhaust. Table 1 lists the main technical parameters of the test diesel engine.

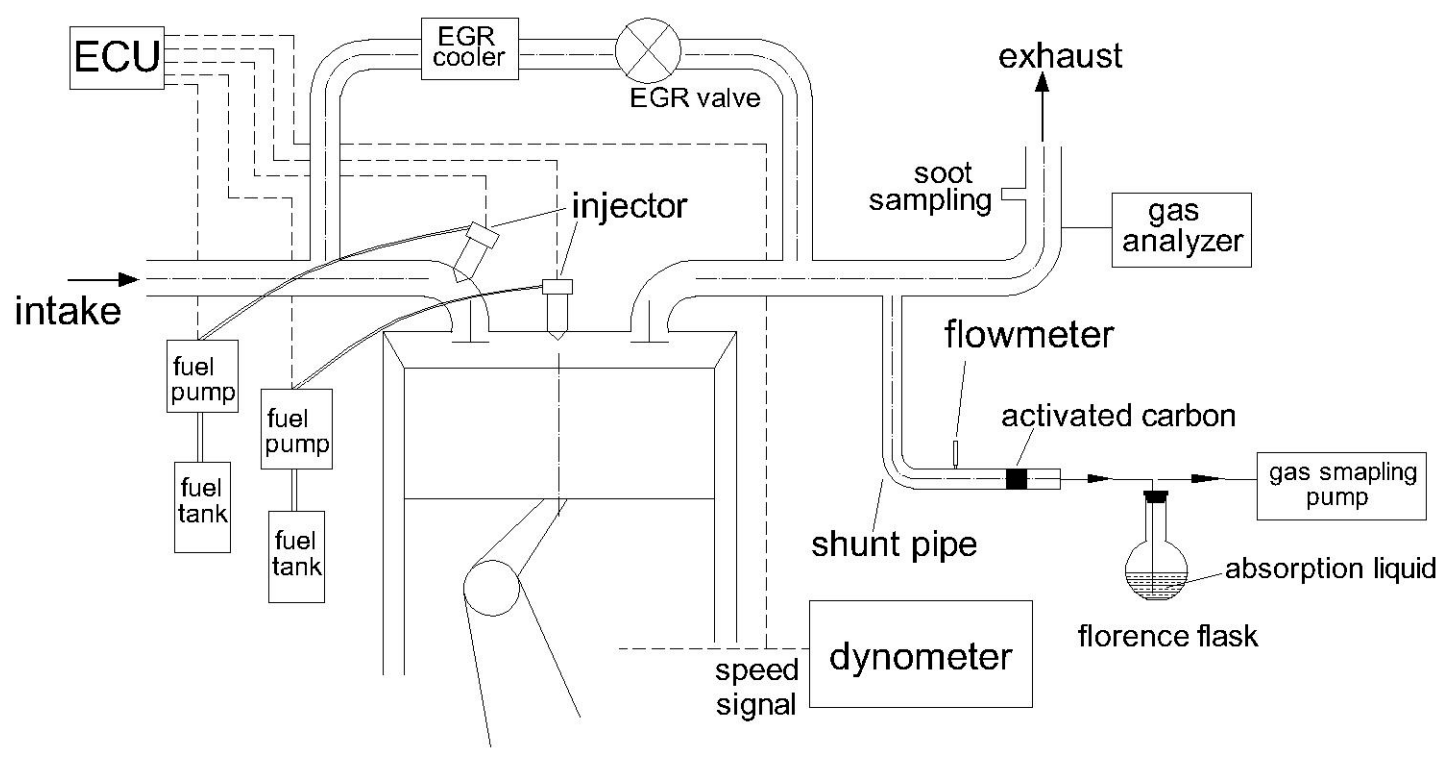

Figure 1. Schematic of the experimental setup.

Table 1. Specifications of the engine.

\begin{tabular}{cc}
\hline Parameters & Details \\
\hline Combustion system & 4 -valve PPCI \\
Number of cylinders & 6 \\
Displacement/bore/stroke & $27 \mathrm{~L} / 170 \mathrm{~mm} / 200 \mathrm{~mm}$ \\
Compression ratio & 14.5 \\
Rated speed/rated power & $1000 \mathrm{r} / \mathrm{min} / 330 \mathrm{~kW}$ \\
Brake specific fuel consumption & $200 \mathrm{~g} /(\mathrm{kW} \times \mathrm{h})$ \\
Injection/injection pressure & Direct injection $/ \mathrm{up} \mathrm{to} 35 \mathrm{MPa}$ \\
Inlet valve opening/closing & $\mathrm{PFI}$ injection $/ 0.45 \mathrm{MPa}$ \\
Exhaust gases valve opening/closing & $50{ }^{\circ} \mathrm{CA} \mathrm{BTDC} / 40^{\circ} \mathrm{CA} \mathrm{ABDC}$ \\
\hline
\end{tabular}


Commercial Euro IV diesel fuel and light hydrocarbon (mainly $\mathrm{C}_{5}, \mathrm{C}_{6}$ ) were adopted in the experiments. In this study, the recommended PPCI scheme was that $85 \%$ light hydrocarbon was premixed with air through port fuel injection (PFI), and 15\% diesel was directly injected into the cylinder. The physical properties of commercial Euro IV diesel fuel and light hydrocarbon are listed in Table 2.

Table 2. Fuel Properties.

\begin{tabular}{ccc}
\hline Properties & Diesel Fuel & Light Hydrocarbon \\
\hline Molecular formula & $\mathrm{C}_{9}-\mathrm{C}_{18}$ compounds & $\mathrm{C}_{5}-\mathrm{C}_{6}$ compounds \\
Liquid density $(\mathrm{kg} / \mathrm{L})$ & $0.82-0.87$ & $0.65-0.68$ \\
Lower heating value $(\mathrm{MJ} / \mathrm{kg})$ & 42.4 & 48.2 \\
Cetane number & 50.8 & - \\
Octane number & - & 70 \\
Flash point $\left({ }^{\circ} \mathrm{C}\right)$ & 54 & -38 \\
Kinematic viscosity $(@ 313 \mathrm{~K})\left(\mathrm{mm}^{2} / \mathrm{s}\right)$ & 2.2 & 0.62 \\
\hline
\end{tabular}

GC-MS is a comprehensive analytical technique, which combines the separation ability of gas chromatography with the identification ability of mass spectrometry. In this paper, an Agilent $6890 \mathrm{~N} / 5975$ gas chromatography/mass spectrometry was adopted. Under each operating condition, $0.5 \mathrm{mg}$ activated carbon granules were taken to make samples. With the CDS Pyrolyzer 5150, samples could be heated rapidly and accurately from room temperature to $1000{ }^{\circ} \mathrm{C}$. Samples placed in pyrolysis tube were pyrolyzed in helium atmosphere. The chemical components, both in particulate and gaseous phase, play a significant role in exhaust gas of engine. While a mass spectrum can contain numerous information representing the highly complex nature of the exhaust gas sample, it also presents considerable challenges for the analysis and interpretation of the sample data. A challenge is the identification and separation of peaks with similar but not identical masses. In this study, specific spectral fitting techniques were needed to resolve the overlapping peaks at the same integer mass, and corresponding squares fit was made to the spectrum by using Squirrel/PIKA software [23]. The pyrolysis products were separated by gas chromatography (GC), and the common pyrolysis products were independently acquired using the same GC-MS conditions and saved as references. The detailed composition of unregulated emissions was then determined through a comparative analysis between the reference standards and the samples of unregulated emissions. The unique interfacing design permits a direct pyrolysis path to the GC inlet or rapid sample heating transfer to the trap without interrupting the pneumatics of the GC-MS Detector for separation and detection. In addition, for the absorbent liquids with exhaust components, $1 \mu \mathrm{L}$ of liquid was taken respectively. The samples could be directly injected from the gas phase inlet, and the relative proportion of each compound in the sample was determined via integration of individual peak regions arising in the GC.

\section{Results and Discussion}

\subsection{Engine Combustion Characteristics}

Figure 2 shows the in-cylinder pressure, heat release rate, and pressure rise rate curves of conventional diesel combustion and PPCI at $100 \%$ engine load of $1000 \mathrm{r} / \mathrm{min}$, respectively. The combustion start time $(\theta \mathrm{s})$ is defined as the crank angle of rapid pressure rising determined by the in-cylinder pressure data. The end time of combustion $(\theta \mathrm{e})$ is defined as the crank angle of the total heat release determined by the heat release rate data. Combustion duration $(\varphi)$ is defined as the interval between $\theta \mathrm{s}$ and $\theta \mathrm{e}$. 


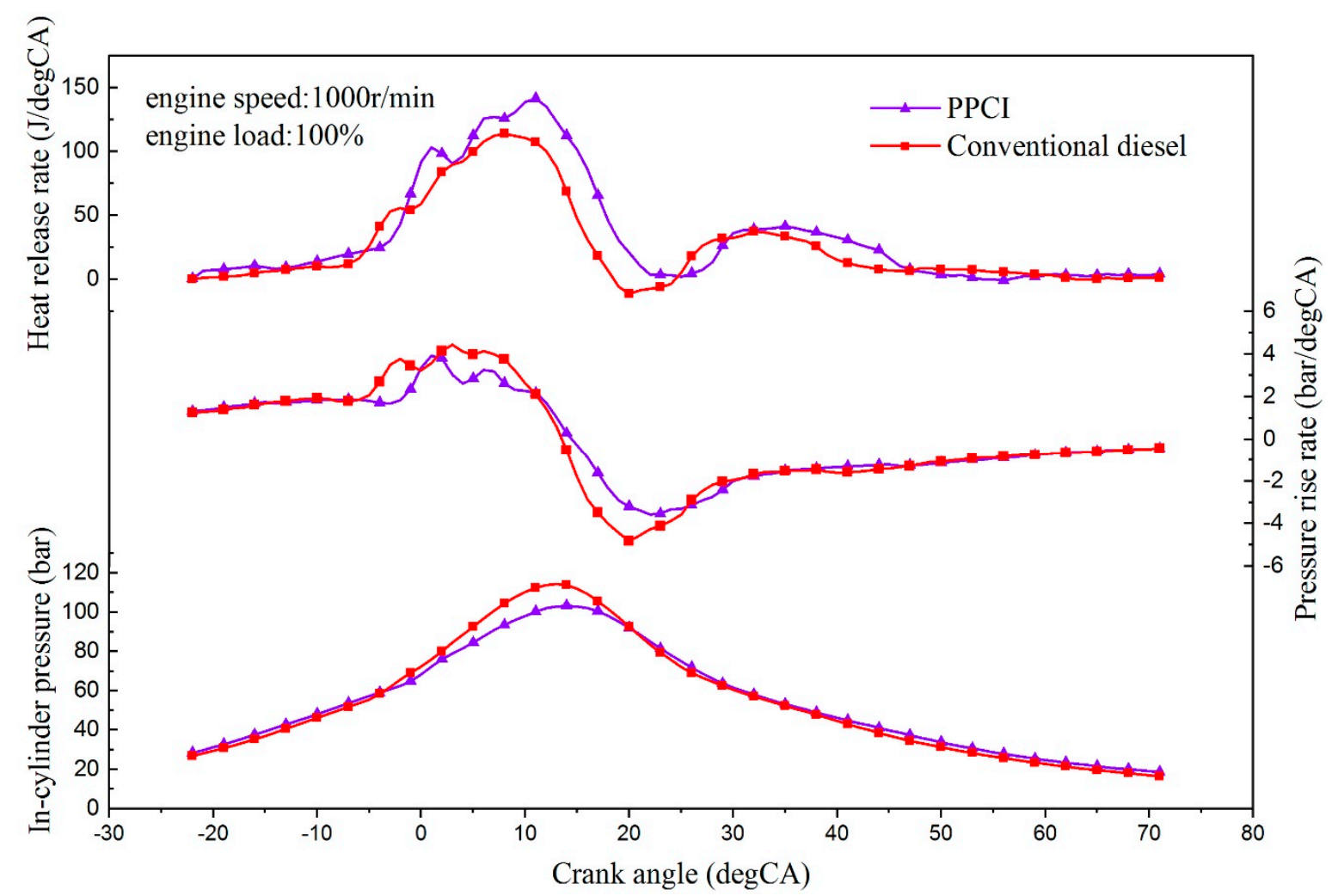

Figure 2. Combustion characteristic curves of conventional diesel combustion and partially premixed compression ignition (PPCI).

As can be seen from Figure 2, compared with conventional diesel combustion, the combustion characteristic curve of PPCI has almost the same trend, that is, the corresponding phases move backwards. For the in-pressure curves at $100 \%$ load, the maximum in-cylinder pressure of PPCI is almost 11 bar lower than that of conventional diesel combustion, and the crank angle at that moment is also delayed by $2{ }^{\circ} \mathrm{CA}$. It is due to fuel properties, atomization process, start of combustion, and ignition delay period $[24,25]$. Although a longer ignition delay can enhance fuel-air mixing and increase the amount of burnt fuel during the premixed phase of the combustion process, the endothermic evaporation of premixed intake charge and heat capacity of premixed fuel decrease as the LHC/Diesel increases, which leads to a decrease of atomization and vaporization characteristics of diesel fuel spray. The maximum pressure rise rate is an indication of the ignition delay of the injected fuel that a higher pressure rise rate is due to a longer delay period. The maximum pressure rise rate of PPCI is reduced by $3.5 \%$ compared to that of conventional diesel combustion, which makes the dual fuel engine work smoothly. It is due to the eminent volatility and low viscosity of LHC which promotes LHC mixing with air during the intake stroke and enhances the ignition performance of the mixture in cylinder. Compared to conventional diesel engine, the maximum heat release rate of PPCI increases by 23.5\% as illustrated in Figure 2. In PPCI combustion, the outstanding atomization and vaporization characteristics facilitates the full mixing of fuel and air, which enhances the mixture combustion rate and complete combustion.

\subsection{GC-MS Detection of Unregulated Emissions}

The unregulated emissions of conventional diesel combustion and PPCI were detected in this paper. The speed was set to $1000 \mathrm{r} / \mathrm{min}$ and the load was $100 \%$ of full load. The chromatographic peak, retention time, and peak area were obtained by chromatograph. In each chromatogram figure, the abscissa represents time, the ordinate represents abundance, and each ion peak represents 
a compound in exhaust gas. Additionally, the number above each ion peak represents the peak time of corresponding species.

Figure 3 is total ion chromatograms (TIC) of unregulated emissions absorbed by activated carbon in conventional diesel combustion, and Table 3 lists the main exhaust components in the order of retention time. Polycyclic aromatic hydrocarbons (PAHs) are created by incomplete combustion or pyrolysis at high temperature under oxygen deficiency during the engine combustion process. In conventional diesel combustion, the semi-volatile fractions of exhaust gas samples are dominated by PAHs and their homologues alkylation series [26]. As illustrated in Figure 3 and Table 3, the peak time of corresponding species is in the range from $3.544 \mathrm{~min}$ to $41.062 \mathrm{~min}$, and the main 41 species are identified based on matching degree. According to the identified species, the peak time mainly focuses on latter part along the retention time axis, which indicates heavy components contained in the exhaust gas of conventional diesel combustion. It is due to the complicated diesel fuel properties and non-premixed combustion mode in conventional diesel engine.

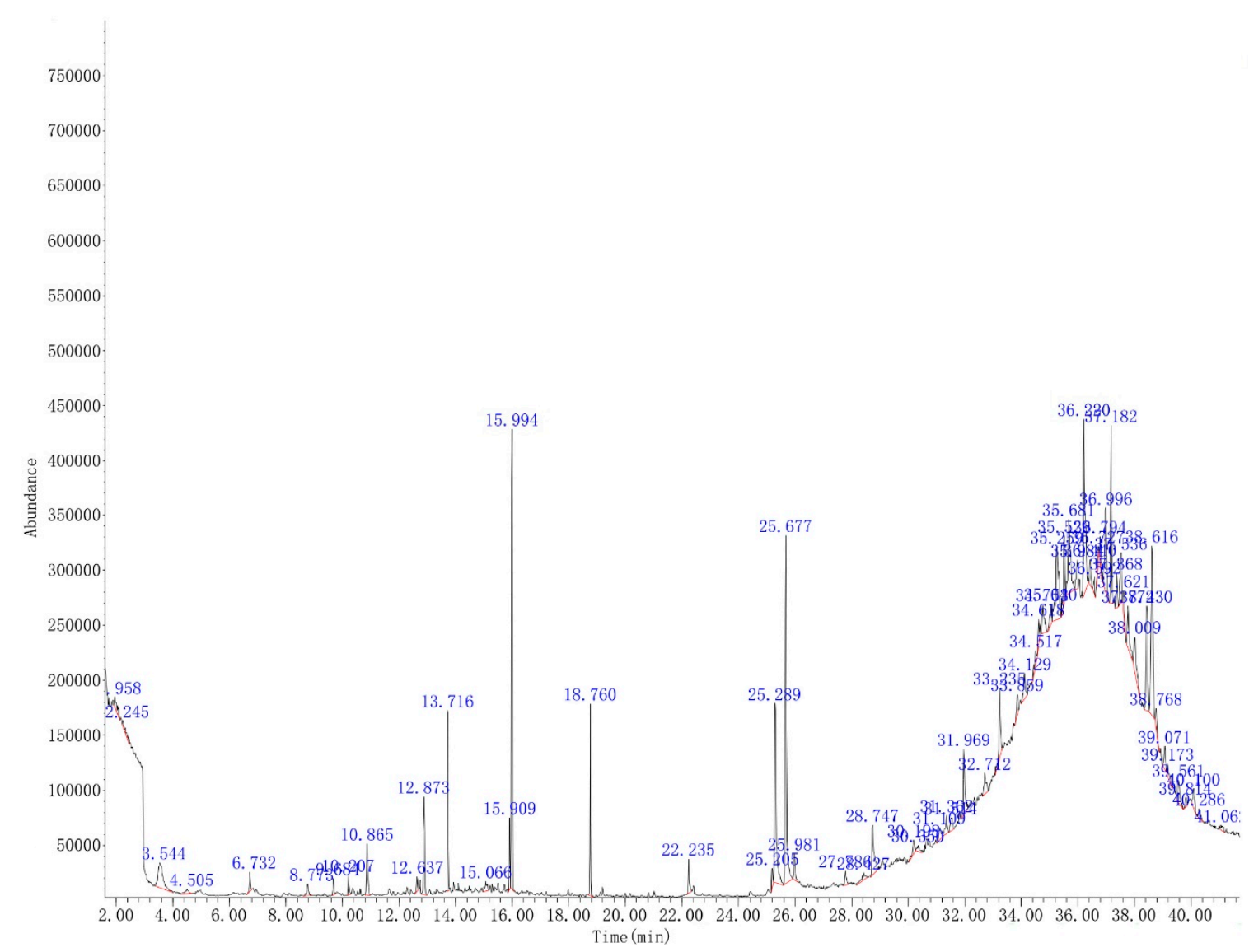

Figure 3. Total ion chromatograms (TIC) of unregulated emissions absorbed by activated carbon in conventional diesel combustion. 
Table 3. Exhaust components absorbed by activated carbon in conventional diesel combustion.

\begin{tabular}{|c|c|c|c|c|}
\hline Number & Retention Time & Name & Formula & Matching Degree \\
\hline 1 & 3.544 & Tetrachloroethylene & $\mathrm{C}_{2} \mathrm{Cl}_{4}$ & 96 \\
\hline 2 & 6.732 & Cyclotetrasiloxane, octamethyl- & $\mathrm{C}_{8} \mathrm{H}_{24} \mathrm{O}_{4} \mathrm{Si}_{4}$ & 90 \\
\hline 3 & 8.773 & Nonanal & $\mathrm{C}_{9} \mathrm{H}_{18} \mathrm{O}$ & 47 \\
\hline 4 & 9.684 & Cyclopentasiloxane, decamethyl- & $\mathrm{C}_{10} \mathrm{H}_{30} \mathrm{O}_{5} \mathrm{Si}_{5}$ & 91 \\
\hline 5 & 10.207 & Benzene, 1,2,4-trichloro- & $\mathrm{C}_{6} \mathrm{H}_{3} \mathrm{Cl}_{3}$ & 97 \\
\hline 6 & 10.865 & Benzene, 1,2,3-trichloro- & $\mathrm{C}_{6} \mathrm{H}_{3} \mathrm{Cl}_{3}$ & 97 \\
\hline 7 & 12.637 & Phthalic anhydride & $\mathrm{C}_{8} \mathrm{H}_{4} \mathrm{O}_{3}$ & 93 \\
\hline 8 & 13.716 & Benzene, 1,2,3,5-tetrachloro- & $\mathrm{C}_{6} \mathrm{H}_{2} \mathrm{Cl}_{4}$ & 98 \\
\hline 9 & 15.066 & $\begin{array}{c}\text { 2-Pentanone, } \\
\text { 4-cyclohexylidene-3,3-diethyl- }\end{array}$ & $\mathrm{C}_{15} \mathrm{H}_{26} \mathrm{O}$ & 43 \\
\hline 10 & 15.909 & Dibenzofuran & $\mathrm{C}_{12} \mathrm{H}_{8} \mathrm{O}$ & 91 \\
\hline 11 & 15.994 & Benzene, pentachloro- & $\mathrm{HC}_{6} \mathrm{Cl}_{5}$ & 99 \\
\hline 12 & 18.76 & Benzene, hexachloro- & $\mathrm{C}_{6} \mathrm{Cl}_{6}$ & 99 \\
\hline 13 & 22.235 & n-Hexadecanoic acid & $\mathrm{C}_{16} \mathrm{H}_{32} \mathrm{O}_{2}$ & 95 \\
\hline 14 & 25.205 & 9,12-Octadecadienoic acid (Z,Z)- & $\mathrm{C}_{18} \mathrm{H}_{32} \mathrm{O}_{2}$ & 99 \\
\hline 15 & 25.289 & 9-Octadecenoic acid,(E)- & $\mathrm{C}_{18} \mathrm{H}_{34} \mathrm{O}_{2}$ & 99 \\
\hline 16 & 25.677 & Octadecanoic acid & $\mathrm{C}_{18} \mathrm{H}_{36} \mathrm{O}_{2}$ & 99 \\
\hline 17 & 25.981 & Hexadecanamide & $\mathrm{C}_{16} \mathrm{H}_{33} \mathrm{NO}$ & 87 \\
\hline 18 & 27.786 & 1-Hexadecanethiol & $\mathrm{C}_{16} \mathrm{H}_{34} \mathrm{~S}$ & 93 \\
\hline 19 & 28.747 & 9-Octadecenamide, (Z)- & $\mathrm{C}_{18} \mathrm{H}_{35} \mathrm{NO}$ & 98 \\
\hline 20 & 31.109 & $\begin{array}{l}\text { 2H-3,9a-Methano-1-benzoxepin, } \\
\text { octahydro-2,2,5a,9-tetramethyl-, } \\
\text { [3R-(3.alpha.,5a.alpha., } \\
\text { 9.alpha.,9a.alpha.)]- }\end{array}$ & $\mathrm{C}_{15} \mathrm{H}_{26} \mathrm{O}$ & 43 \\
\hline 21 & 31.362 & 2-(Nonyloxycarbonyl)benzoic acid & $\mathrm{C}_{17} \mathrm{H}_{24} \mathrm{O}_{4}$ & 55 \\
\hline 22 & 31.969 & Heneicosane & $\mathrm{C}_{21} \mathrm{H}_{44}$ & 97 \\
\hline 23 & 33.235 & Heptacosane, 1-chloro & $\mathrm{C}_{27} \mathrm{H}_{55} \mathrm{Cl}$ & 99 \\
\hline 24 & 34.129 & Cholest-22-ene, (5.alpha.)- & $\mathrm{C}_{27} \mathrm{H}_{46}$ & 53 \\
\hline 25 & 34.517 & $\begin{array}{l}\text { 1-Methyl-4-(1-methylethyl)-3-[1- } \\
\text { methyl-1-(4-methylpentyl)-5- } \\
\text { methylheptyl]cyclohexene }\end{array}$ & $\mathrm{C}_{25} \mathrm{H}_{50}$ & 72 \\
\hline 26 & 34.753 & $\begin{array}{l}\text { D-Homoandrostane, (5.alpha., } \\
\text { 13.alpha.)- }\end{array}$ & $\mathrm{C}_{20} \mathrm{H}_{34}$ & 93 \\
\hline 27 & 35.259 & 17.alfa.,21.beta.-28,30-Bisnorhopane & $\mathrm{C}_{28} \mathrm{H}_{48}$ & 64 \\
\hline 28 & 35.681 & $\begin{array}{c}\text { Butanamide, } \\
\text { 3-(3-fluorobenzoylhydrazono)-N- } \\
\text { (4-fluorobenzyl)- }\end{array}$ & $\mathrm{C}_{18} \mathrm{H}_{17} \mathrm{~F}_{2} \mathrm{~N}_{3} \mathrm{O}_{2}$ & 60 \\
\hline 29 & 35.984 & $\begin{array}{l}\text { Urs-20-en-16-ol, (16.beta., 18.alpha., } \\
\text { 19.alpha.)- }\end{array}$ & $\mathrm{C}_{30} \mathrm{H}_{50} \mathrm{O}$ & 59 \\
\hline 30 & 36.22 & 23,28-Bisnor-17.beta.(H)-hopane & $\mathrm{C}_{28} \mathrm{H}_{48}$ & 81 \\
\hline 31 & 36.794 & $\begin{array}{c}\text { Antra-9,10-quinone, } \\
\text { 1-(3-hydrohy-3-phenyl-1-triazenyl)- }\end{array}$ & $\mathrm{C}_{20} \mathrm{H}_{13} \mathrm{~N}_{3} \mathrm{O}_{3}$ & 68 \\
\hline 32 & 37.536 & 28-Nor-17.alpha.(H)-hopane & $\mathrm{C}_{29} \mathrm{H}_{50}$ & 86 \\
\hline 33 & 37.621 & Baccharane & $\mathrm{C}_{30} \mathrm{H}_{54}$ & 84 \\
\hline 34 & 38.43 & D:A-Friedooleanane & $\mathrm{C}_{30} \mathrm{H}_{52}$ & 50 \\
\hline
\end{tabular}


Table 3. Cont.

\begin{tabular}{|c|c|c|c|c|}
\hline Number & Retention Time & Name & Formula & Matching Degree \\
\hline 35 & 38.616 & $\begin{array}{c}\text { 1-Penten-3-one, } \\
\text { 1-(2,6,6-trimethyl-1-cyclohexen-1-yl)- }\end{array}$ & $\mathrm{C}_{14} \mathrm{H}_{22} \mathrm{O}$ & 45 \\
\hline 36 & 39.071 & $\begin{array}{l}\text { 9,10-Methanoanthracen-11-ol, } \\
\text { 9,10-dihydro-9,10,11-trimethyl- }\end{array}$ & $\mathrm{C}_{18} \mathrm{H}_{18} \mathrm{O}$ & 46 \\
\hline 37 & 39.561 & 1H-Indole, 1-methyl-2-phenyl- & $\mathrm{C}_{15} \mathrm{H}_{13} \mathrm{~N}$ & 43 \\
\hline 38 & 39.814 & $\begin{array}{c}\text { Anthracene, } \\
\text { 9,10-dihydro-9,9,10-trimethyl- }\end{array}$ & $\mathrm{C}_{17} \mathrm{H}_{18}$ & 55 \\
\hline 39 & 40.286 & \multicolumn{2}{|c|}{ 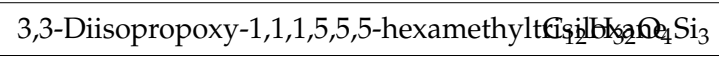 } & 50 \\
\hline 40 & 40.1 & $\begin{array}{l}\text { 1H-Indole-2-carboxylic acid, } \\
\text { 6-(4-ethoxyphenyl)-3-methyl-4-oxo-4,5,6, } \\
\text { 7-tetrahydro-, isopropyl ester }\end{array}$ & $\mathrm{C}_{25} \mathrm{H}_{50}$ & 41 \\
\hline 41 & 41.062 & Benzo[h]quinolone, 2,4-dimethyl- & $\mathrm{C}_{15} \mathrm{H}_{13} \mathrm{~N}$ & 46 \\
\hline
\end{tabular}

Figure 4 is TIC of unregulated emissions absorbed by absorption liquid in conventional diesel combustion, and Table 4 lists the main exhaust components in the order of retention time. Volatile organic compounds (VOCs) in the $\mathrm{C}_{6}-\mathrm{C}_{11}$ range of diesel engine exhaust gas have been reported in literature [26], while little studies on heavy components with longer carbon chains were discussed. As shown in Figure 4 and Table 4, the retention time of corresponding species is in the range from $2.298 \mathrm{~min}$ to $28.782 \mathrm{~min}$, and about 21 species are identified on account of matching degree. In the retention time from $23.16 \mathrm{~min}$ to $28.782 \mathrm{~min}$, alkane species with long carbon chains are observed due to the evaporation and pyrolysis of diesel fuel incomplete combustion in high temperature at $100 \%$ engine load.

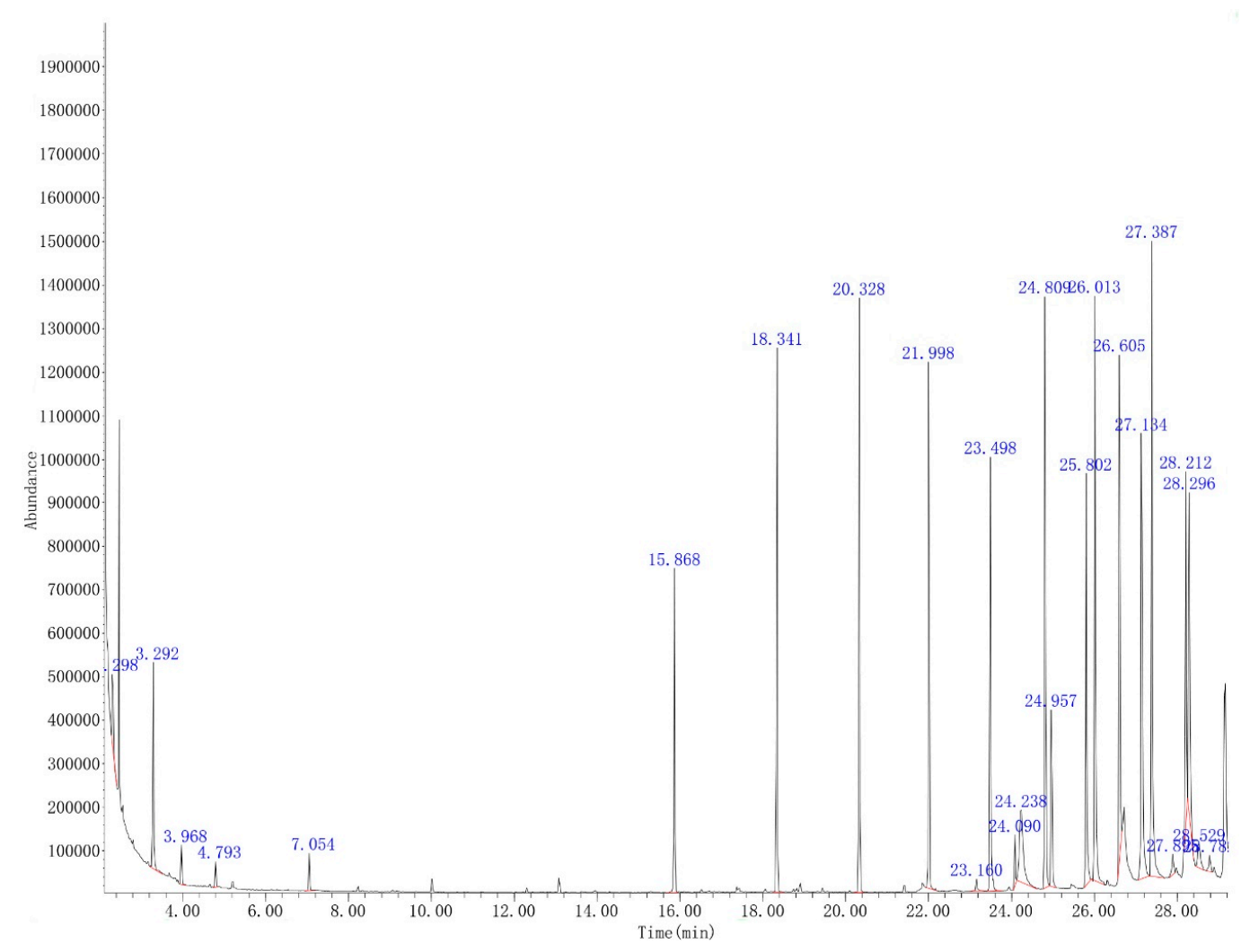

Figure 4. TIC of unregulated emissions absorbed by absorption liquid in conventional diesel combustion. 
Table 4. Exhaust components absorbed by absorption liquid in conventional diesel combustion.

\begin{tabular}{ccccc}
\hline Number & $\begin{array}{c}\text { Retention } \\
\text { Time }\end{array}$ & Name & Formula & $\begin{array}{c}\text { Matching } \\
\text { Degree }\end{array}$ \\
\hline 1 & 2.298 & n-Hexane & $\mathrm{C}_{6} \mathrm{H}_{14}$ & 60 \\
2 & 3.292 & Toluene & $\mathrm{C}_{7} \mathrm{H}_{8}$ & 91 \\
3 & 3.968 & 1,2-Bis(trimethylsilyl)benzene & $\mathrm{C}_{12} \mathrm{H}_{22} \mathrm{Si}_{2}$ & 83 \\
4 & 4.793 & p-Xylene & $\mathrm{C}_{8} \mathrm{H}_{10}$ & 95 \\
5 & 7.054 & Cyclotetrasiloxane, octamethyl- & $\mathrm{C}_{8} \mathrm{H}_{24} \mathrm{O}_{4} \mathrm{Si}_{4}$ & 90 \\
6 & 15.868 & Cycloheptasiloxane, tetradecamethyl- & $\mathrm{C}_{14} \mathrm{H}_{42} \mathrm{O}_{7} \mathrm{Si}_{7}$ & 91 \\
7 & 18.341 & Cyclooctasiloxane, hexadecamethyl- & $\mathrm{C}_{16} \mathrm{H}_{48} \mathrm{O}_{8} \mathrm{Si}_{8}$ & 91 \\
8 & 20.328 & Cyclononasiloxane, octadecamethyl- & $\mathrm{C}_{18} \mathrm{H}_{54} \mathrm{O}_{9} \mathrm{Si}_{9}$ & 94 \\
9 & 21.998 & Cyclodecasiloxane, eicosamethyl- & $\mathrm{C}_{20} \mathrm{H}_{60} \mathrm{O}_{10} \mathrm{Si}_{10}$ & 49 \\
10 & 23.16 & Heneicosane & $\mathrm{C}_{21} \mathrm{H}_{44}$ & 98 \\
11 & 24.09 & Docosane & $\mathrm{C}_{22} \mathrm{H}_{46}$ & 99 \\
12 & 24.238 & Nonacosane & $\mathrm{C}_{29} \mathrm{H}_{60}$ & 99 \\
13 & 24.957 & $\mathrm{C}_{20} \mathrm{H}_{42}$ & 93 \\
14 & 25.802 & Nonadecane, 9-methyl- & $\mathrm{C}_{24} \mathrm{H}_{50}$ & 99 \\
15 & 26.605 & Tetracosane & $\mathrm{C}_{25} \mathrm{H}_{52}$ & 99 \\
16 & 27.387 & Pentacosane & $\mathrm{C}_{26} \mathrm{H}_{54}$ & 98 \\
17 & 27.895 & Hexacosane & $\mathrm{C}_{23} \mathrm{H}_{19} \mathrm{~N}_{3}$ & 35 \\
18 & 28.212 & $\mathrm{C}_{27} \mathrm{H}_{56}$ & 99 \\
19 & 28.296 & Benzoic acid, 2,5-bis(trimethylsiloxy)-, & $\mathrm{C}_{16} \mathrm{H}_{30} \mathrm{O}_{4} \mathrm{Si}_{3}$ & 55 \\
20 & 28.529 & trimethylsilyl ester & $\mathrm{C}_{20} \mathrm{H}_{42}$ & 96 \\
21 & 28.782 & Eicosane & $\mathrm{C}_{26} \mathrm{H}_{54}$ & 49 \\
\hline
\end{tabular}

Figure 5 is TIC of unregulated emissions absorbed by activated carbon in PPCI, and Table 5 lists the main exhaust components in the order of retention time. As illustrated in Figure 5 and Table 5, the peak time of corresponding species is in the range from 3.409 min to $37.165 \mathrm{~min}$, and the main 13 species are identified based on matching degree. Compared to conventional diesel combustion, fewer PAHs are identified in PPCI. That is because PPCI has sufficient time to mix with fresh air in intake stroke which improves the oxygen deficit condition in fuel-rich regions during the mixture formation process [27].

Table 5. Exhaust components absorbed by activated carbon in PPCI.

\begin{tabular}{ccccc}
\hline Number & $\begin{array}{c}\text { Retention } \\
\text { Time }\end{array}$ & Name & Formula & $\begin{array}{c}\text { Matching } \\
\text { Degree }\end{array}$ \\
\hline 1 & 3.409 & Fumaronitrile & $\mathrm{C}_{4} \mathrm{H}_{2} \mathrm{~N}_{2}$ & 43 \\
2 & 4.050 & $\mathrm{C}_{7} \mathrm{H}_{12} \mathrm{O}$ & 38 \\
3 & 12.653 & 2-Cyclohexen-1-ol, 3-methyl- & $\mathrm{C}_{8} \mathrm{H}_{4} \mathrm{O}_{3}$ & 53 \\
4 & 15.724 & Phthalic anhydride & $\mathrm{C}_{14} \mathrm{H}_{22} \mathrm{O}$ & 78 \\
5 & 15.926 & Phenol, 3,5-bis(1,1-dimethylethyl)- & $\mathrm{C}_{12} \mathrm{H}_{8} \mathrm{O}$ & 78 \\
6 & 31.362 & Dibenzofuran & $\mathrm{C}_{24} \mathrm{H}_{38} \mathrm{O}_{4}$ & 72 \\
7 & 33.994 & 3is(2-ethylhexyl) phthalate & $\mathrm{C}_{12} \mathrm{H}_{32} \mathrm{O}_{4} \mathrm{Si}_{3}$ & 35 \\
8 & 37.165 & Benzo[h]quinoline, 2,4-dimethyl- & $\mathrm{C}_{15} \mathrm{H}_{13} \mathrm{~N}$ & 43 \\
\hline
\end{tabular}




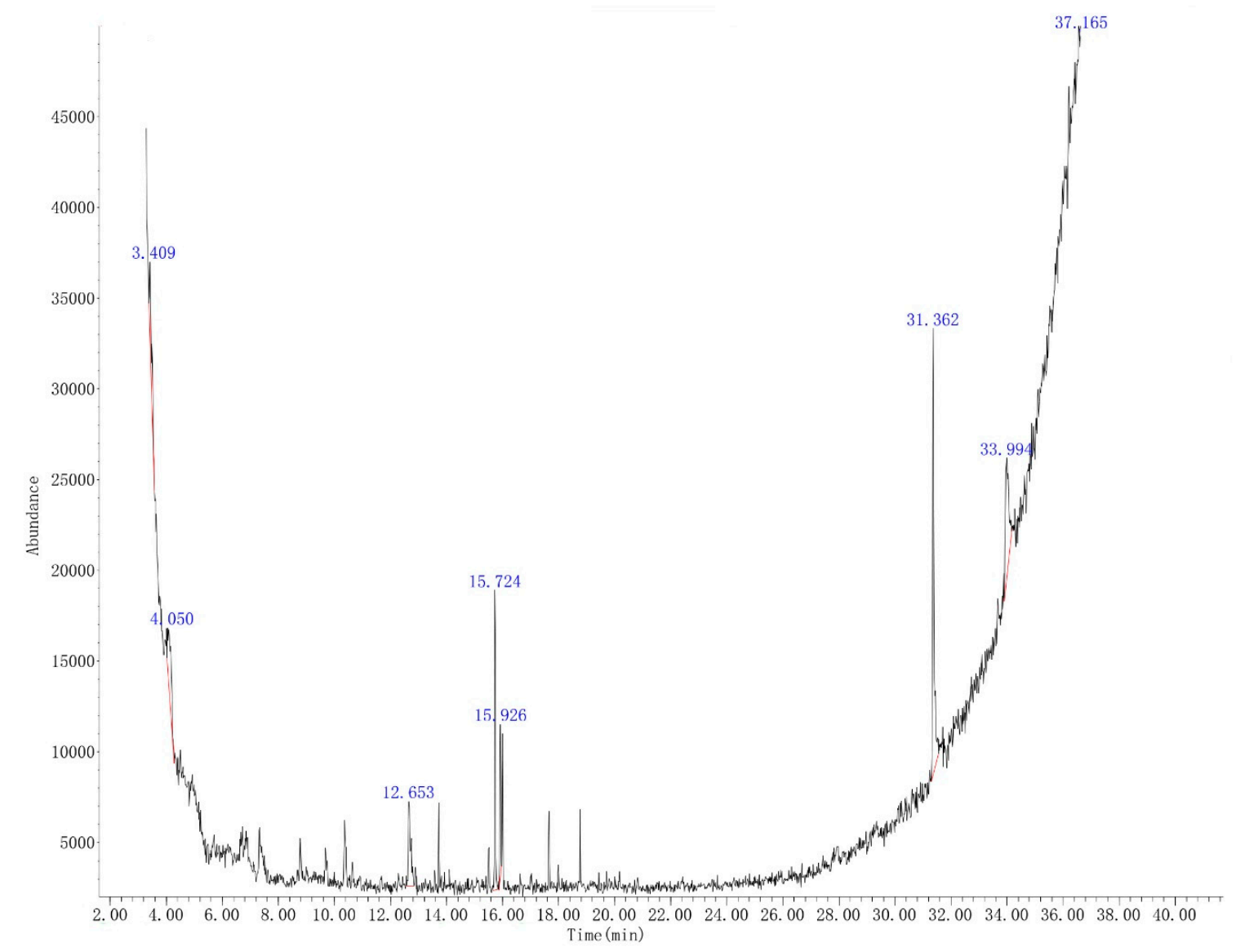

Figure 5. TIC of unregulated emissions absorbed by activated carbon in PPCI.

Figure 6 is TIC of unregulated emissions absorbed by absorption liquid in PPCI, and Table 6 lists the main exhaust components in the order of retention time. As shown in Figure 6 and Table 6, the retention time of corresponding species is in the range from $2.319 \mathrm{~min}$ to $27.641 \mathrm{~min}$, and about seven species are identified on account of matching degree. Compared to conventional diesel combustion, fewer VOCs in PPCI are also identified. Compared to diesel fuel, LHC has short carbon chains and most of them represent straight chains, which produces fewer polycyclic aromatic hydrocarbons and other gaseous components [28]. In addition, LHC presents higher volatility and retarded ignition characteristics which facilitates fuel droplet mixing with air sufficiently and further homogeneous mixture is formed. The above-mentioned factors give rise to fewer PAHs and other gaseous components formation in PPCI.

Table 6. Exhaust components absorbed by absorption liquid in PPCI.

\begin{tabular}{ccccc}
\hline Number & Retention Time & Name & Formula & Matching Degree \\
\hline 1 & 2.319 & Acetic acid, trichloro-, ethyl ester & $\mathrm{C}_{4} \mathrm{H}_{5} \mathrm{Cl}_{3} \mathrm{O}_{2}$ & 10 \\
2 & 2.489 & Pentane, 2,2,4-trimethyl- & $\mathrm{C}_{8} \mathrm{H}_{18}$ & 64 \\
3 & 3.292 & Toluene & $\mathrm{C}_{7} \mathrm{H}_{8}$ & 93 \\
4 & 3.968 & Cyclotrisiloxane, hexamethyl- & $\mathrm{C}_{6} \mathrm{H}_{18} \mathrm{O}_{3} \mathrm{Si}_{3}$ & 78 \\
5 & 4.814 & Cyclotrisiloxane, hexamethyl- & $\mathrm{C}_{6} \mathrm{H}_{18} \mathrm{O}_{3} \mathrm{Si}_{3}$ & 47 \\
6 & 7.054 & Cyclotetrasiloxane, octamethyl- & $\mathrm{C}_{8} \mathrm{H}_{24} \mathrm{O}_{4} \mathrm{Si}_{4}$ & 78 \\
7 & 27.641 & Tetrasiloxane, decamethyl- & $\mathrm{C}_{10} \mathrm{H}_{30} \mathrm{O}_{3} \mathrm{Si}_{4}$ & 38 \\
\hline
\end{tabular}




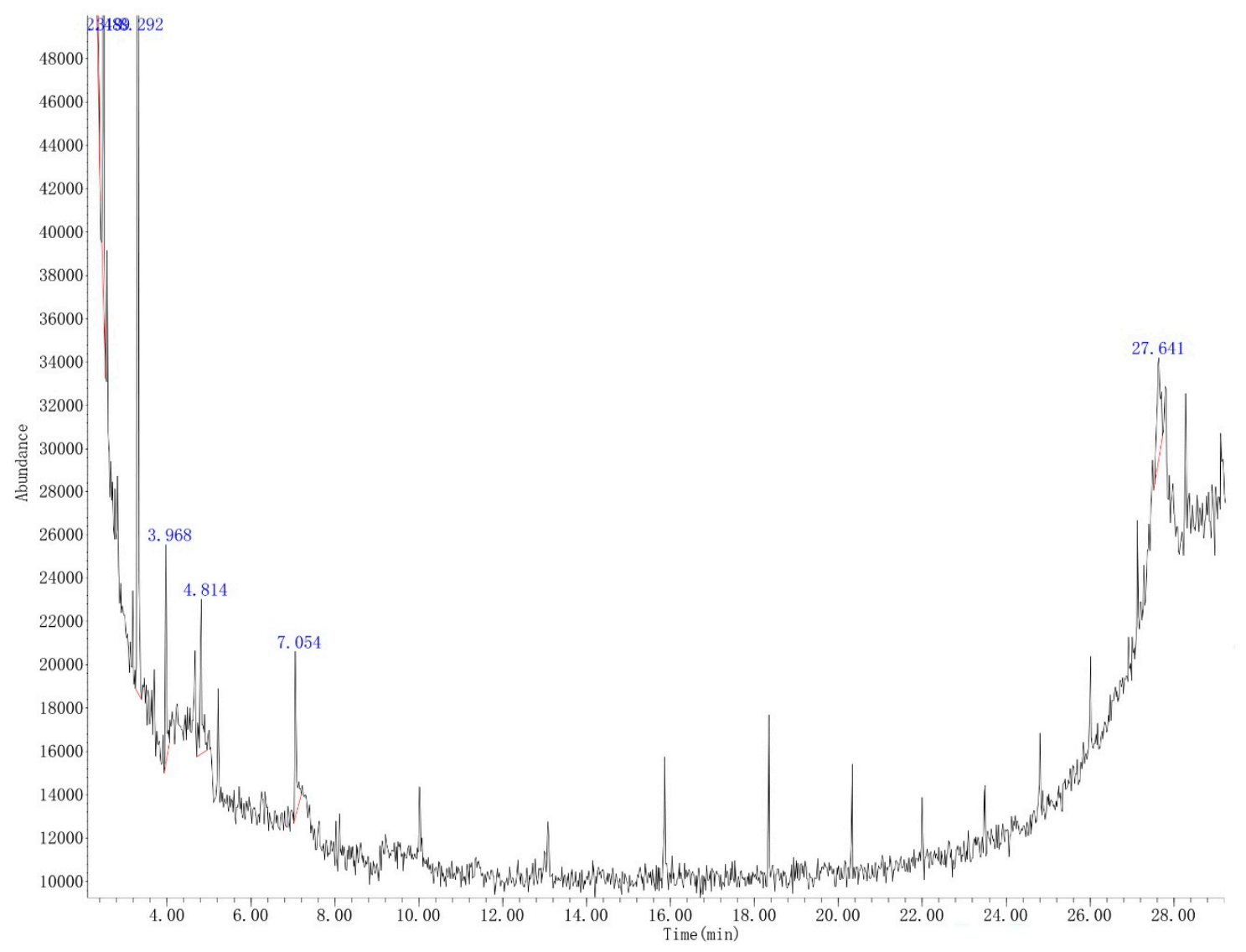

Figure 6. TIC of unregulated emissions absorbed by absorption liquid in PPCI.

Mass spectrogram was obtained by mass spectrometer, and standard spectrogram was used for retrieval and analysis. The mass-charge ratio $(\mathrm{m} / \mathrm{z})$ and its strength of different ions could be adopted to determine the relative molecular mass of organic compounds, so as to determine the chemical formula of the compounds. Due to the complexity of unregulated emissions in conventional diesel combustion, the compounds with matching degree less than $40 \%$ were disregarded, and for those with the same molecular formulas, the one with a higher matching degree was retained. For PPCI, all the test results of unregulated emissions were retained.

As shown in Tables 3-6, there are more components detected in activated carbon than in absorption liquid, indicating that the unregulated emissions of diesel engine exhaust are mostly macromolecular substances. Apparently, the unregulated emissions components in PPCI are much less than those in conventional diesel combustion. From the molecular formula, the emissions components in conventional diesel combustion are more complex, and carbon content of compounds is larger. The main elements of unregulated emissions in conventional diesel combustion are $\mathrm{C}, \mathrm{H}, \mathrm{O}, \mathrm{N}, \mathrm{Si}$, and $\mathrm{Cl}$ as reported in literature $[26,29,30]$. Among them, $\mathrm{N}$ mainly comes from air, and Si may exist in lubrication oil as well as $\mathrm{Cl}$ mainly exists in diesel fuel. As a halogenated element about $\mathrm{Cl}$, it can easily replace hydrogen to produce halogenated hydrocarbons.

It can also be seen from Figures 3-6 and Tables 3-6 that the unregulated emissions components in PPCI are much less than that in conventional diesel combustion at full load condition, no matter what detected from activated carbon or absorption liquid. Further, the peak time of most components in conventional diesel combustion is later than that in PPCI, which indicates that there are more heavy components in the exhaust of conventional diesel combustion. The probable cause may be related to the fuel properties [31,32]. The light hydrocarbons used in this paper are mainly pentane and hexane, while the compositions of commercial diesel fuel are more complex. 


\subsection{Semi-Quantitative Analysis on Unregulated Emissions}

In this study, the relative concentration of components in unregulated emissions between conventional diesel combustion and PPCI was represented with the relative peak area by using semi-quantitative method in GC-MS software [25]. Some hydrocarbons, including olefins, alkynes, and cyclohexanes, are considered to be extremely toxic [33,34]. In this paper, for example, 28-Nor-17.alpha. (H)-hopane, and (5.alpha.)-Cholest-22-ene are considered to be harmful substances. Alcohols mainly include $(16 . \beta, 18 . \alpha, 19 . \alpha)$-Urs-20-en-16-ol, 3-methyl-2-Cyclohexen-1-ol and other complex alcohols. Esters include Acetic acid, trichloro-, ethyl ester, and Bis(2-ethylhexyl) phthalate. Bis(2-ethylhexyl) phthalate is an environmental hormone that binds to hormone receptors in the body and can interfere with the maintenance of normal levels of hormones in the blood, affecting human reproduction, development, and behavior. Long-term exposure to environmental hormones can cause chronic harm to human body, mainly manifested in reproductive toxicity to humans and animals. Acids include n-Hexadecanoic acid, octadecanoic acid and some complex acids. Aldehydes are mainly nonanal and heptanal, which, similar to acids, can irritate the skin and eyes to varying degrees, and long-term contact can also corrode the skin. Organosilicon compound is mainly siloxane, which is inflammable and can irritate eyes and skin. Inhalation may result in reduced central nervous system function. As illustrated in Figure 7, others in activated carbon are mostly chlorinated compounds, such as Tetrachloroethylene and Pentachloro-benzene.

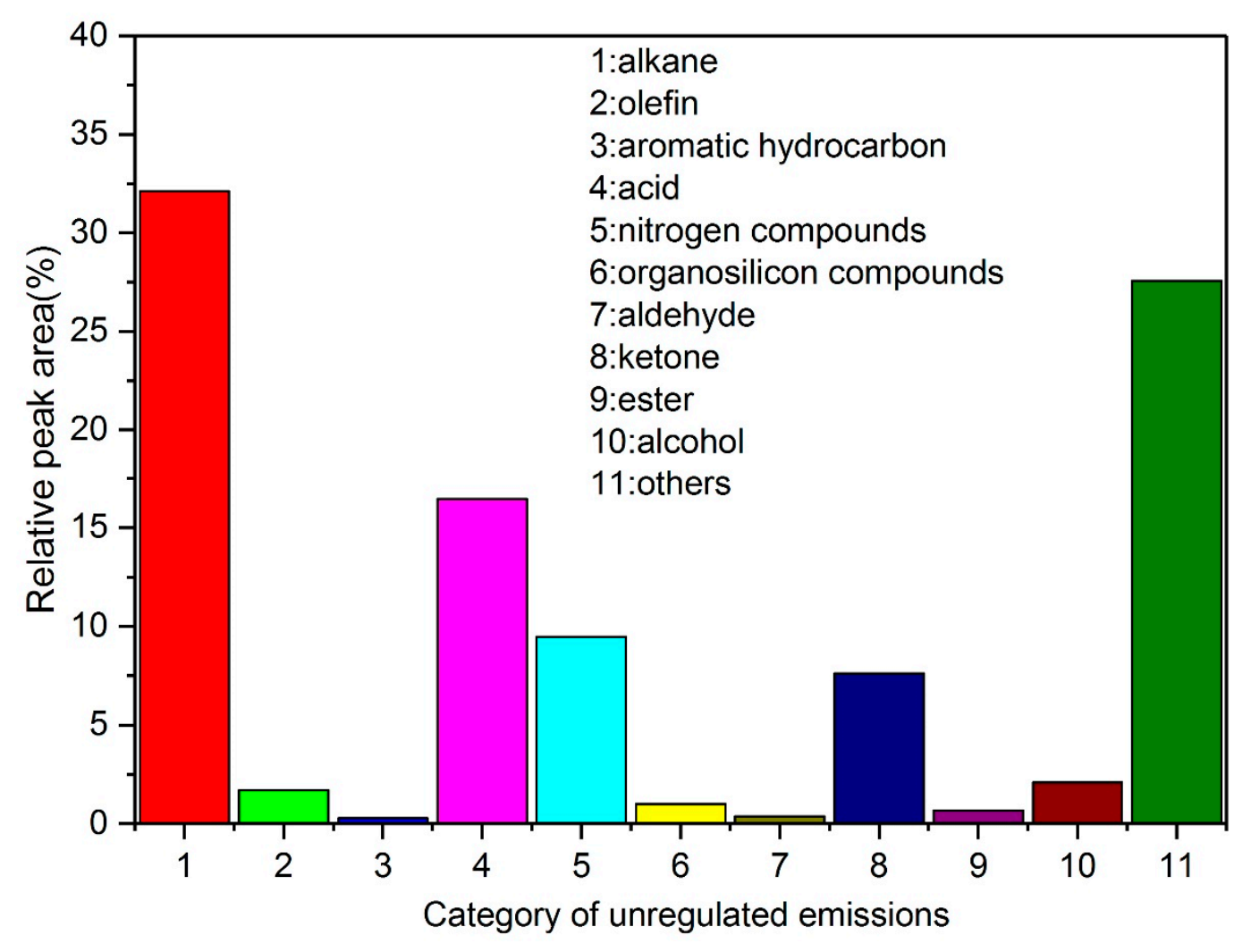

Figure 7. Relative concentration of unregulated emissions absorbed by activated carbon in conventional diesel combustion.

Figure 7 illustrates the relative concentration of unregulated emissions absorbed by activated carbon in conventional diesel combustion. As shown in Figure 7, the relative concentration of primary unregulated emissions by activated carbon is: Alkane $32.12 \%$, acid $16.45 \%$, nitrogen compounds $9.48 \%$, and ketone $7.62 \%$.

Figure 8 shows the relative concentration of unregulated emissions absorbed by absorption liquid in conventional diesel combustion. As shown in Figure 8, the relative concentration of primary 
unregulated emissions by absorption liquid is: Alkane $35.49 \%$, organosilicon compounds $61.27 \%$, and aromatic hydrocarbon $2.79 \%$.

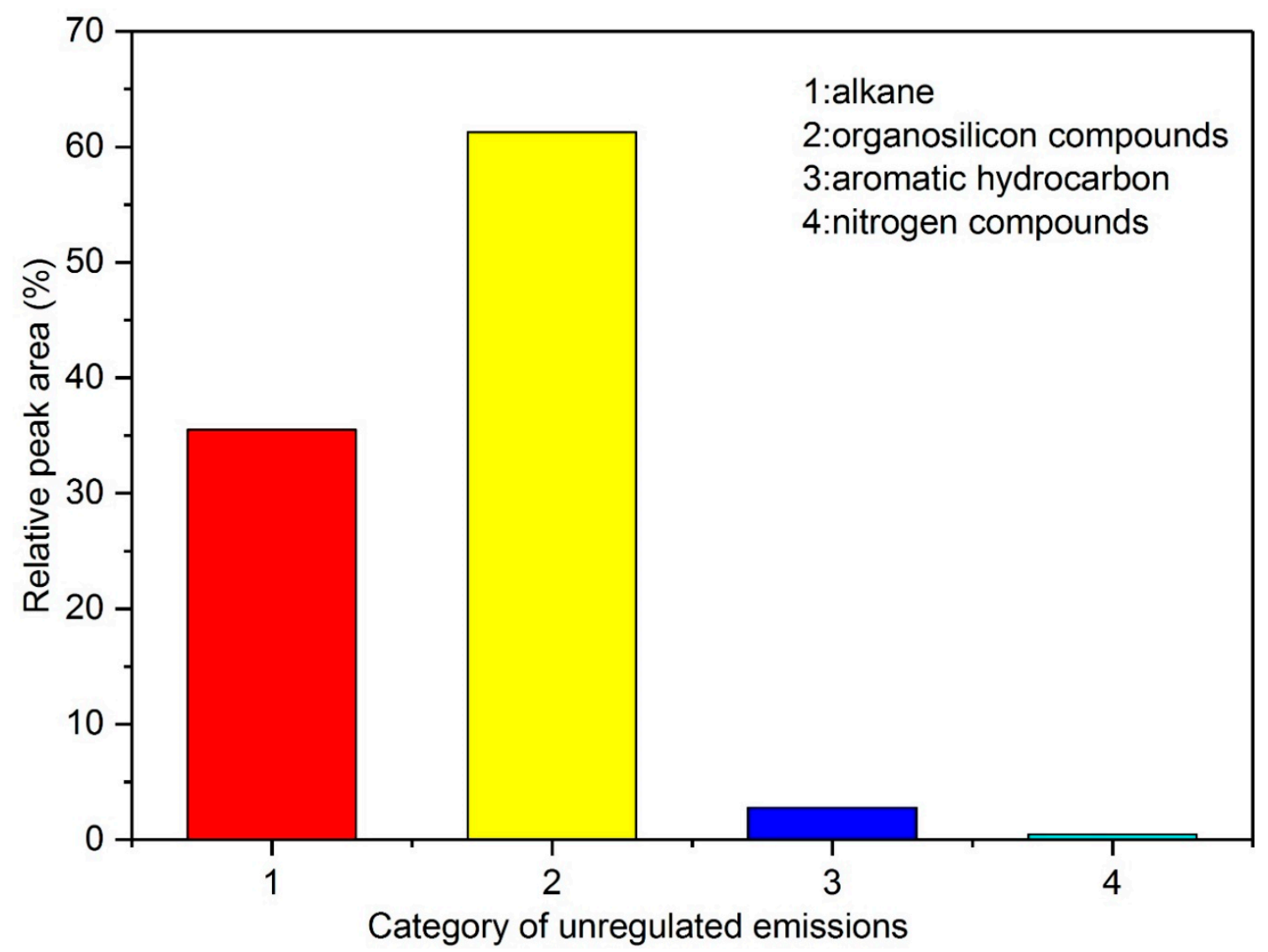

Figure 8. Relative concentration of unregulated emissions absorbed by absorption liquid in conventional diesel combustion.

Figure 9 illustrates the relative concentration of unregulated emissions absorbed by activated carbon in PPCI. As shown in Figure 9, the relative concentration of primary unregulated emissions by activated carbon is: Ketone $80.51 \%$, ester $4.77 \%$, and organosilicon compounds $2.70 \%$.

Figure 10 shows the relative concentration of unregulated emissions absorbed by absorption liquid in PPCI. As shown in Figure 10, the relative concentration of primary unregulated emissions by absorption liquid is: Ester $40.23 \%$, aromatic hydrocarbon $24.56 \%$, alkane $18.30 \%$, and organosilicon compounds $16.91 \%$. 


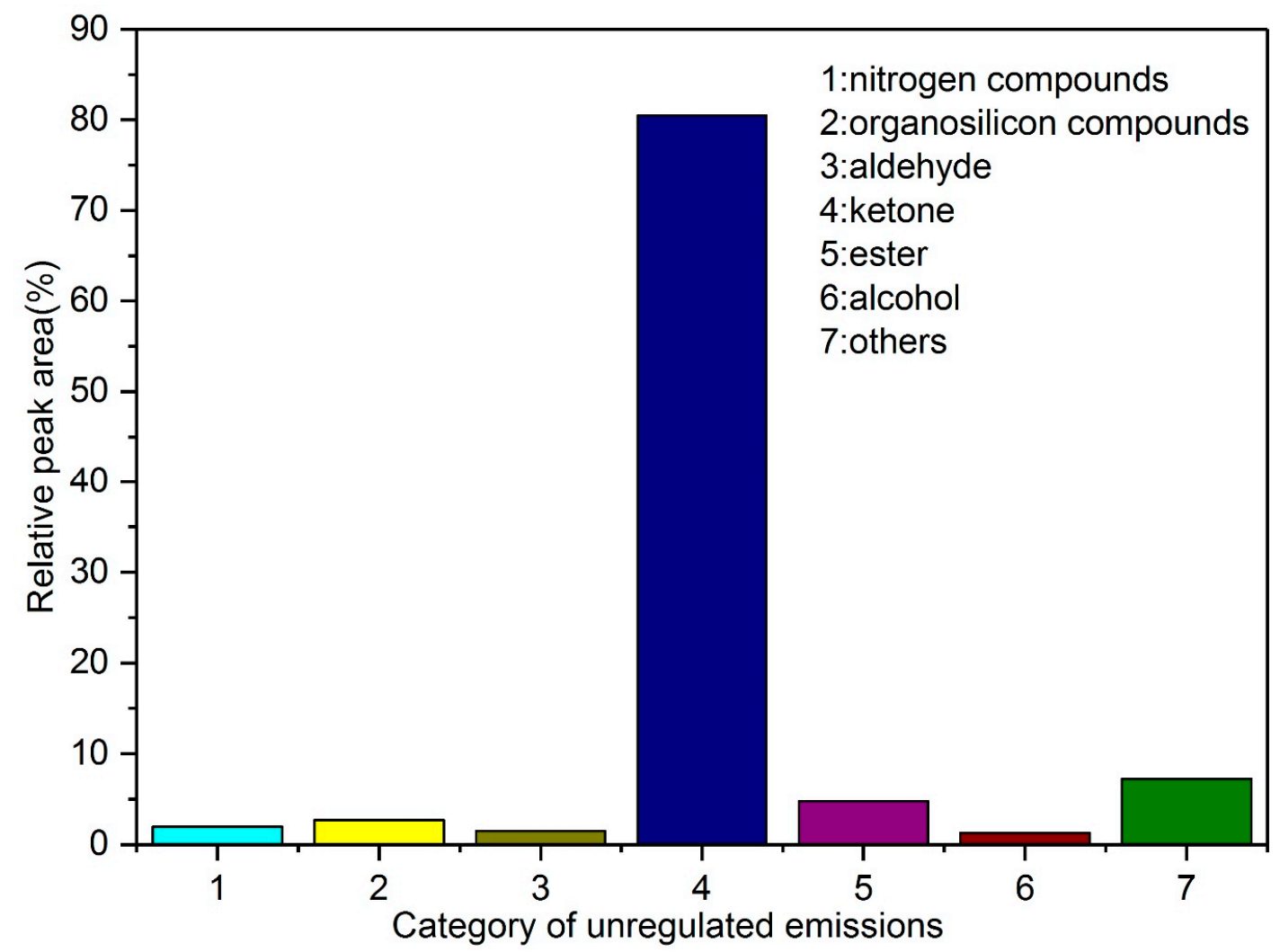

Figure 9. Relative concentration of unregulated emissions absorbed by activated carbon in PPCI.

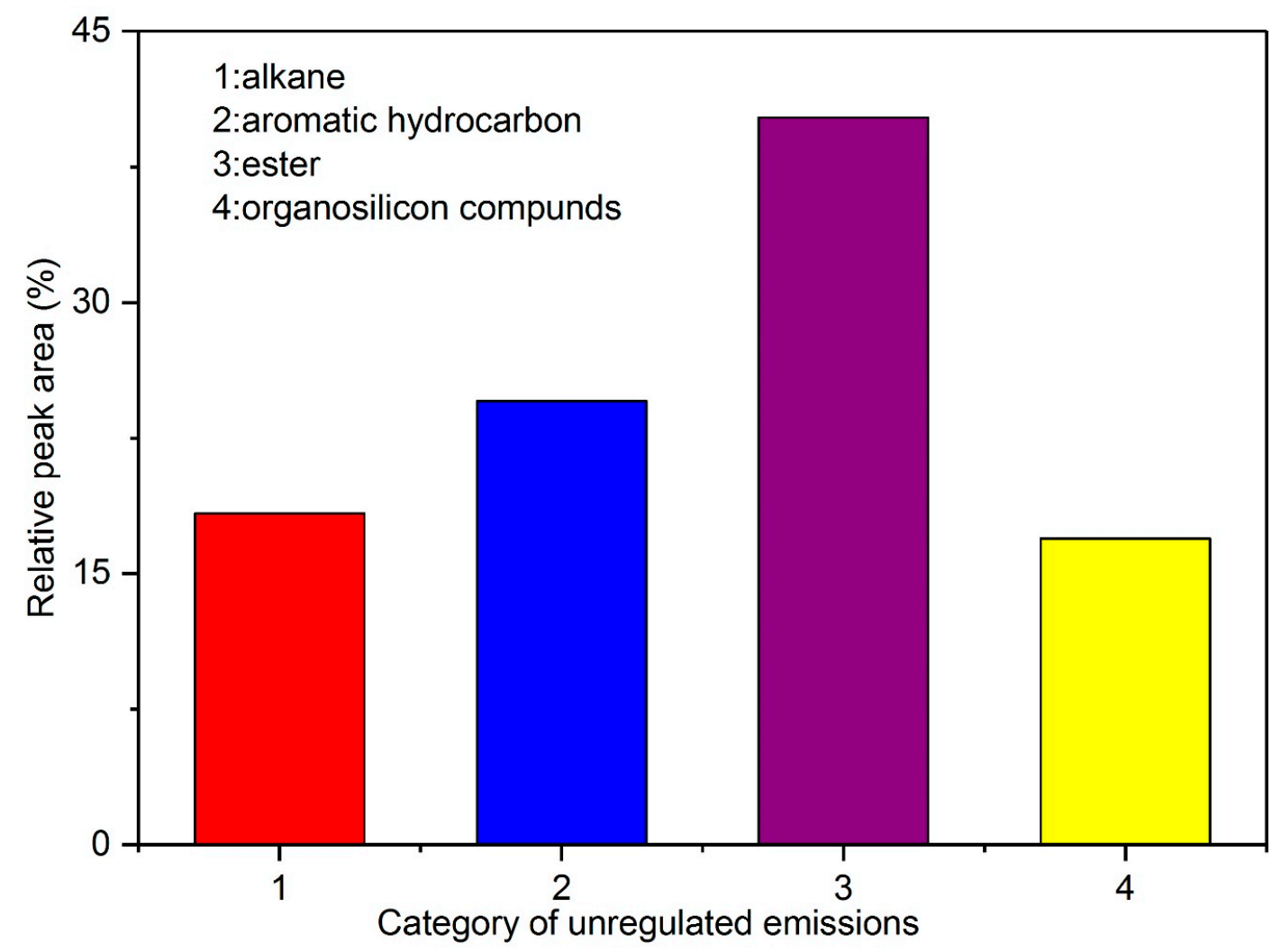

Figure 10. Relative concentration of unregulated emissions absorbed by absorption liquid in PPCI. 
Compared to conventional diesel combustion, the relative concentration of alkane and organic components in PPCI decreases significantly, while ketone and ester increase as illustrated in Figures 7-10. Similarly to what has been observed for high molecular weight alkane as reported in literature [35], the formation of these compounds is due to the higher engine load where large amounts of fuel is demanded, resulting in evaporation and pyrolysis of fuel [36]. In addition, these unregulated components can also be pyrosynthesised in the combustion process from the lubrication oil constituents [37].

\section{Conclusions}

In this study, the unregulated emissions of a conventional diesel self-ignition and partial premixed compression ignition marine engine at full load condition were detected, classified, and semi-quantitatively analyzed, respectively. According to the results and discussion presented above, the main conclusions can be summarized as follows:

- For the in-pressure curves at $100 \%$ load, the maximum in-cylinder pressure of PPCI is almost 11 bar lower than that of conventional diesel combustion, and the crank angle at that moment is also delayed by $2{ }^{\circ} \mathrm{CA}$. Compared to conventional diesel combustion, the maximum pressure rise rate of PPCI is reduced by $3.5 \%$, while the maximum heat release rate of PPCI increases by $23.5 \%$.

- Total ion chromatograms are obtained by chromatograph, and species detected in PPCI unregulated emissions are much less than those in conventional diesel combustion. Further, the peak time of PPCI component is earlier than that of conventional diesel combustion.

- Compared to conventional diesel combustion, the relative concentration of alkane and organic components in PPCI decreases significantly, while ketone and ester increase.

Author Contributions: Investigation, X.W.; writing-original draft preparation, M.W.; project administration, Y.H.; writing-review and editing, X.W. and H.C. All authors have read and agreed to the published version of the manuscript.

Funding: This research was funded by "China Scholarship Council (CSC 201908420387)”, “open fund of National Synchrotron Radiation Laboratory (NSRL) in Hefei (2018-HLS-PT-001746)", "State Key Laboratory of Engines at Tianjin University (K2018-09)", and "research fund of Center for Materials Research and Analysis, WHUT (2018KFJJ07)".

Acknowledgments: The authors would like to thank Dingcheng Machinery Manufacturing Co. Ltd. for financial support. The authors gratefully acknowledge Kai Xu for beneficial discussions on GC-MS measurement.

Conflicts of Interest: The authors declare no conflict of interest.

\section{References}

1. Moon, G.; Lee, Y.; Choi, K.; Jeong, D. Emission characteristics of diesel, gas to liquid, and biodiesel-blended fuels in a diesel engine for passenger cars. Fuel 2010, 89, 3840-3846. [CrossRef]

2. Agarwal, A.K.; Shukla, P.C.; Patel, C.; Gupta, J.G.; Sharma, N.; Prasad, R.K.; Agarwal, R.A. Unregulated emissions and health risk potential from biodiesel (KB5, KB20) and methanol blend (M5) fuelled transportation diesel engines. Renew. Energy 2016, 98, 283-291. [CrossRef]

3. Gowtham, M.; Mohan, C.; Prakash, R. Effect of n-butanol fumigation on the regulated and unregulated emission characteristics of a diesel engine. Fuel 2019, 242, 84-95. [CrossRef]

4. Qian, Y.; Chen, F.; Zhang, Y.; Tao, W.; Han, D.; Lu, X. Combustion and regulated/unregulated emissions of a direct injection spark ignition engine fueled with C3-C5 alcohol/gasoline surrogate blends. Energy 2019, 174, 779-791. [CrossRef]

5. Cheung, C.S.; Zhu, L.; Huang, Z. Regulated and unregulated emissions from a diesel engine fueled with biodiesel and biodiesel blended with methanol. Atmos. Environ. 2009, 43, 4865-4872. [CrossRef]

6. Man, X.; Cheung, C.S.; Ning, Z.; Wei, L.; Huang, Z. Influence of engine load and speed on regulated and unregulated emissions of a diesel engine fueled with diesel fuel blended with waste cooking oil biodiesel. Fuel 2016, 180, 41-49. [CrossRef] 
7. Tang, S.; Frank, B.P.; Lanni, T.; Rideout, G.; Meyer, N.; Beregszaszy, C. Unregulated Emissions from a Heavy-Duty Diesel Engine with Various Fuels and Emission Control Systems. Environ. Sci. Technol. 2007, 41, 5037-5043. [CrossRef]

8. Agarwal, A.K.; Shukla, P.C.; Gupta, J.G.; Patel, C.; Prasad, R.K.; Sharma, N. Unregulated emissions from a gasohol (E5, E15, M5, and M15) fuelled spark ignition engine. Appl. Energy 2015, 154, 732-741. [CrossRef]

9. Zhang, Z.; Cheung, C.S.; Chan, T.L.; Yao, C. Experimental investigation of regulated and unregulated emissions from a diesel engine fueled with Euro V diesel fuel and fumigation methanol. Atmos. Environ. 2010, 44, 1054-1061. [CrossRef]

10. Tsunemoto, H.; Ishitani, H.; Kaimai, T. Type Effect of Fuel Properties on Unburned HC and Particulate Matter Emissions in a Small Dl Diesel Engine; SAE Technical Paper 2001-01-3387; SAE International in United States: Troy, MI, USA, 1 October 2001.

11. Li, Z.; Liu, G.; Cui, X.; Sun, X.; Li, S.; Qian, Y.; Jiang, C.; Lu, X. Effects of the variation in diesel fuel components on the particulate matter and unregulated gaseous emissions from a common rail diesel engine. Fuel 2018, 232, 279-289. [CrossRef]

12. Velji, A.; Yeom, K.; Wagner, U.; Spicher, U.; Rossbach, M.; Suntz, R.; Bockhorn, H. Investigations of the Formation and Oxidation of Soot Inside a Direct Injection Spark Ignition Engine Using Advanced Laser-Techniques; SAE Technical Paper 2010-01-0352; SAE International in United States: Troy, MI, USA, 12 April 2010.

13. Flowers, D.; Aceves, S.; West brook, C.K.; Smith, J.R.; Dibble, R. Detailed chemical kinetic simulation of natural gas HCCI combustion: Gas composition effects and investigation of control strategies. J. Eng. Gas Turbines Power 2001, 23, 433-439. [CrossRef]

14. Cheng, C.; Cheung, C.S.; Chan, T.L.; Lee, S.-C.; Yao, C.; Tsang, K. Comparison of emissions of a direct injection diesel engine operating on biodiesel with emulsified and fumigated methanol. Fuel 2008, 87, 1870-1879. [CrossRef]

15. Pastor, J.V.; Garcia-Oliver, J.M.; Garcia, A.; Mico, C.; Durrett, R. A spectroscopy study of gasoline partially premixed self-ignition spark assisted combustion. Appl. Energy 2013, 104, 568-575. [CrossRef]

16. Won, H.W.; Peters, N.; Tait, N.; Kalghatgi, G. Sufficiently premixed self-ignition of a gasoline-like fuel using three different nozzles in a diesel engine. J. Automob. Eng. 2012, 226, 698-708. [CrossRef]

17. Valentino, G.; Corcione, F.E.; Iannuzzi, S.E. Effects of gasoline-diesel and n-butanol-diesel blends on performance and emissions of an automotive direct-injection diesel engine. Int. J. Engine Res. 2012, 13, 199-215. [CrossRef]

18. An, Y.; Jaasim, M.; Vallinayagam, R.; Vedharaj, S.; Im, H.G.; Johansson, B. Numerical simulation of combustion and soot under partially premixed combustion of low-octane gasoline. Fuel 2018, 211, 420-431. [CrossRef]

19. Qu, X.; Gong, C.; Liu, J.; Cui, F.; Liu, F. Regulated and unregulated emissions from a DISI methanol engine under homogenous combustion and light load. Fuel 2015, 158, 166-175. [CrossRef]

20. Wang, H.; Ge, Y.; Tan, J.; Hao, L.; Peng, Z.; Wang, X.; Wu, L.; Li, Y.; Yang, J.; Li, J.; et al. The effects of ash inside a platinum-based catalyst diesel particulate filter on particle emissions, gaseous emissions, and unregulated emissions. Environ. Sci. Pollut. Res. 2018, 25, 33736-33744. [CrossRef]

21. Xiao, H.; Wang, R.; Zeng, P.; Jiang, A.; Hou, B.; Yang, S. Particulate matter and unregulated emissions of diesel engine fueled with 2-methylfuran diesel blends. Fuel 2017, 208, 168-173. [CrossRef]

22. Gong, C.; Liu, J.; Peng, L.; Liu, F. Numerical study of effect of injection and ignition timings on combustion and unregulated emissions of DISI methanol engine during cold start. Renew. Energy 2017, 112, 457-465. [CrossRef]

23. Zhang, Y.; Peräkylä, O.; Yan, C.; Heikkinen, L.; Äijälä, M.; Daellenbach, K.R.; Zha, Q.; Riva, M.; Garmash, O.; Junninen, H.; et al. A novel approach for simple statistical analysis of high-resolution mass spectra. Atmos. Meas. Tech. 2019, 12, 3761-3776. [CrossRef]

24. Rajak, U.; Nashine, P.; Verma, T.N.; Pugazhendhi, A. Performance, combustion and emission analysis of microalgae Spirulina in a common rail direct injection diesel engine. Fuel 2019, 255, 115855. [CrossRef]

25. Nour, M.; Attia, A.M.; Nada, S.A. Improvement of CI engine combustion and performance running on ternary blends of higher alcohol (Pentanol and Octanol)/hydrous ethanol/diesel. Fuel 2019, 251, 10-22. [CrossRef]

26. Alves, C.A.; Barbosa, C.; Rocha, S.; Calvo, A.I.; Nunes, T.; Cerqueira, M.; Pio, C.; Karanasiou, A.; Querol, X. Elements and polycyclic aromatic hydrocarbons in exhaust particles emitted by light-duty vehicles. Environ. Sci. Pollut. Res. 2015, 22, 11526-11542. [CrossRef] [PubMed] 
27. Gaddam, C.K.; Wal, R.L.V. Physical and chemical characterization of SIDI engine particulates. Combust. Flame 2013, 160, 2517-2528. [CrossRef]

28. Chen, H.; Wang, M.; Wang, X.; Li, D.; Pan, Z.; Bae, C. Experimental investigation of particulate matter structures under partially premixed combustion in a compression ignition engine. Fuel 2020, 259, 116286. [CrossRef]

29. Choi, S.; Seong, H. Lube oil-dependent ash chemistry on soot oxidation reactivity in a gasoline direct-injection engine. Combust. Flame 2016, 174, 68-76. [CrossRef]

30. Lim, J.; Lim, C.; Yu, L.E. Composition and size distribution of metals in diesel exhaust particulates. J. Environ. Monit. 2009, 11, 1614. [CrossRef]

31. Song, J.; Lee, K.O. Fuel Property Impacts on Diesel Particulate Morphology, Nanostructures, and NOx Emissions; SAE Technical Paper 2007-01-0129; SAE International in United States: Troy, MI, USA, 16 April 2007.

32. Wisniewski, A., Jr.; Wiggers, V.R.; Simionatto, E.L.; Meier, H.F.; Barros, A.A.C.; Madureira, L.A.S. Biofuels from waste fish oil pyrolysis: Chemical composition. Fuel 2010, 89, 563-568. [CrossRef]

33. Macor AAvella, F.; Faedo, D. Effects of $30 \%$ v/v biodiesel/diesel fuel blend on regulated and unregulated pollutant emissions from diesel engines. Appl. Energy 2011, 88, 4989-5001. [CrossRef]

34. Cosseron, A.-F.; Bennadji, H.; Leyssens, G.; Coniglio, L.; Daou, T.J.; Tschamber, V. Evaluation and Treatment of Carbonyl Compounds and Fine Particles Emitted by Combustion of Biodiesels in a Generator. Energy Fuels 2012, 26, 6160-6167. [CrossRef]

35. Liu, Z.G.; Berg, D.R.; Swor, T.A.; Schauer, J.J. Comparative Analysis on the Effects of Diesel Particulate Filter and Selective Catalytic Reduction Systems on a Wide Spectrum of Chemical Species Emissions. Environ. Sci. Technol. 2008, 42, 6080-6085. [CrossRef] [PubMed]

36. Nelson, P.F.; Tibbett, A.R.; Day, S.J. Effects of vehicle type and fuel quality on real world toxic emissions from diesel vehicles. Atmos. Environ. 2008, 42, 5291-5303. [CrossRef]

37. Wang, W.G.; Clark, N.N.; Lyons, D.W.; Yang, R.M.; Gautam, M.; Bata, R.M.; Loth, J.L. Emissions Comparisons from Alternative Fuel Buses and Diesel Buses with a Chassis Dynamometer Testing Facility. Environ. Sci. Technol. 1997, 31, 3132-3137. [CrossRef]

(C) 2020 by the authors. Licensee MDPI, Basel, Switzerland. This article is an open access article distributed under the terms and conditions of the Creative Commons Attribution (CC BY) license (http://creativecommons.org/licenses/by/4.0/). 